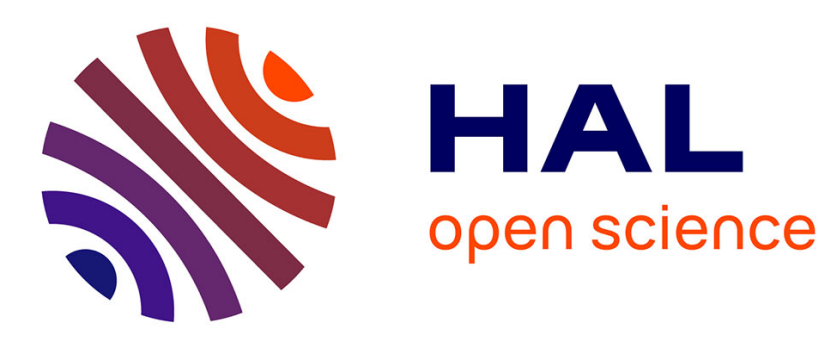

\title{
An Ox-powered Paddlewheel Boat. Virtual Reconstruction of a 4th Century Roman Machine
}

Philippe Fleury, Sophie Madeleine

\section{To cite this version:}

Philippe Fleury, Sophie Madeleine. An Ox-powered Paddlewheel Boat. Virtual Reconstruction of a 4th Century Roman Machine. XXXIX Conference on Computer Applications and Quantitative Methods in Archaeology: Revive the past, Apr 2001, Beijing, China. pp.125-131. hal-01596414

\section{HAL Id: hal-01596414 https://hal.science/hal-01596414}

Submitted on 2 Oct 2017

HAL is a multi-disciplinary open access archive for the deposit and dissemination of scientific research documents, whether they are published or not. The documents may come from teaching and research institutions in France or abroad, or from public or private research centers.
L'archive ouverte pluridisciplinaire HAL, est destinée au dépôt et à la diffusion de documents scientifiques de niveau recherche, publiés ou non, émanant des établissements d'enseignement et de recherche français ou étrangers, des laboratoires publics ou privés. 


\section{Proceedingsof the}

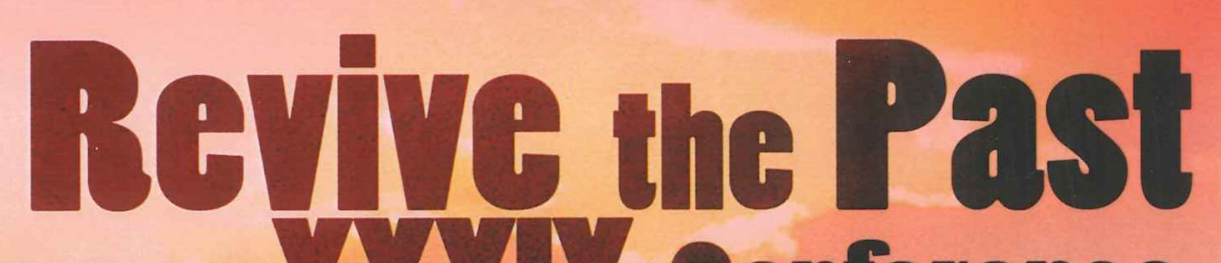

on GomputerApplications and Quantitative methods
in Archaeology

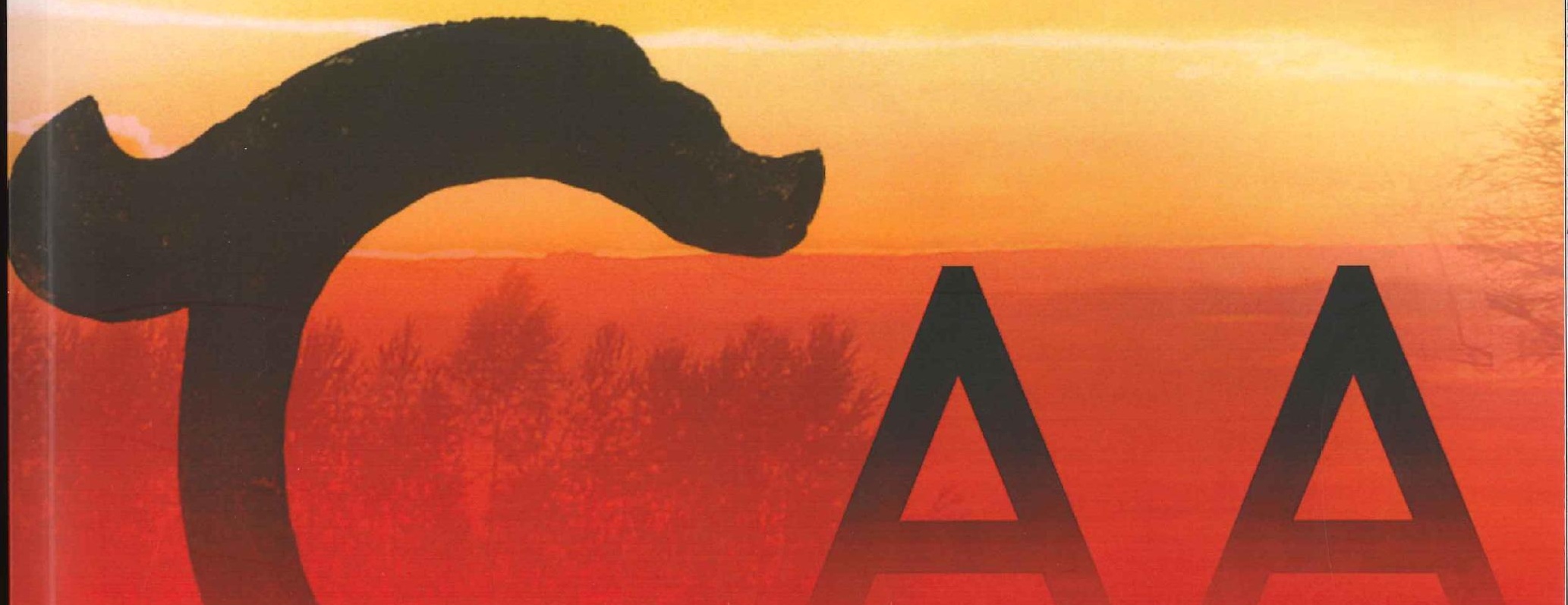

Beijing 12-16 April 2011

Mingquan Zhou, Iza Romanowska, Zhongke Wu, Pengfei Xu, Philip Verhagen

\section{PallasPublications}




\title{
Revive the Past
}

\author{
Proceeding of the $39^{\text {th }}$ Conference on Computer \\ Applications and Quantitative Methods in Archaeology
}

Beijing, 12-16 April 2011

Edited by

Mingquan Zhou, Iza Romanowska, Zhongke Wu, Pengfei Xu and Philip Verhagen

Pallas Publications 


\title{
An Ox-powered Paddlewheel Boat. Virtual Reconstruction of a $4^{\text {th }}$ Century Roman Machine
}

\author{
Philippe Fleury \\ Université de Caen Basse-Normandie, France.philippe.fleury@unicaen.fr \\ Sophie Madeleine \\ Université de Caen Basse-Normandie, France.sophie.madeleine@unicaen.fr
}

\begin{abstract}
:
This paper will focus on the virtual reconstruction of a war machine, an ox-powered Roman paddle wheel boat used for its impressive speed during naval manoeuvres. The ship is described and drawn in an anonymous 4th century work but is often considered as imaginary by researchers. This is the first time, to our knowledge, that the reconstruction of this ship has been attempted and we shall show, through the experiment with a $3 D$ model, that this warship of antiquity can work and, even more so, that it is probably the ancestor of the paddle steamer. Through this reconstruction, we would like to insist on the value of experimental history produced using scientifically justified virtual reconstructions, a medium of the future to develop innovative educational applications and write new pages in the history of science and technology.
\end{abstract}

Key Words: Virtual Reality, History of Technology, Roman Machinery

An anonymous Latin treatise of the $4^{\text {th }}$ century AD, known as De Rebus Bellicis, describes, among a number of new mechanical contrivances, which in the opinion of its author ought to form part of the equipment of the Roman army, an ox-powered paddlewheel liburnian. There is no other data to accredit the use of this system, no archaeological or iconographical evidence so researchers are dubious about this text. One of the first modern editors of De Rebus Bellicis, R. Schneider (1908), wrote: "Die Liburna ist geradezu verrückt" ("The liburnian is just crazy"), and recently, in 1989 A. Giardina considered that, if the chariot à faux, described by Anonymous was at first a reality on the battlefield, and then a legend of military engineering, the paddlewheel boat is exactly the contrary: born as a fantastic machine powered by oxen, it is steam which finally provided the invention with a real application (Giardina 1989). The aim of this paper is to show that this self-propelled liburnian, described in De Rebus Bellicis, can be reconstructed with the text transmitted (and its illustrations) and with indications provided by technical knowledge in antiquity. The virtual reconstruction will show that the liburnian can work and that it could have been built and used in antiquity. It is an important challenge for the history of technology because, if this hypothesis is correct, the first propulsion of a boat with a paddlewheel should no longer be ascribed to Denis Papin at the end of the $17^{\text {th }}$ century (with a steam engine), or to Robert Fulton at the beginning of the $19^{\text {th }}$ century for the operational model: this technology would thus go back thirteen centuries at least, with an animal-driven engine. First, we will look to the text itself, its reliability, and the illustrations in the manuscripts. Then, we will study a history of the techniques in order to find indications lending credence to the system. To conclude, the virtual reconstruction of the liburnian will be shown. 
CAA2011 - Revive the Past: Proceedings of the 39th Conference in Computer Applications and Quantitative Methods in Archaeology, Beijing, China, 12-16 April 2011

\section{Ancient Source Materials}

De Rebus Bellicis is a short anonymous treatise in which the author sends to the emperor some proposals for reforms in fiscal, monetary and military matters (Condorelli 1971; Giardina 1989; Jouffroy 2004; Reinach 1922; Thompson 1952). The author was not a "mechanical engineer" as was Vitruvius, the author of $D e$ Architectura in the first century AD If we had to qualify him by modern notions, we would speak about a specialist in economic and financial affairs. The title given to his treatise ("Military Affairs"), probably in a late period, is inappropriate since war machines concern no more than half of the work. At the time of the writing, the author was not exercising an official function, but the vocabulary which he uses to deal with administrative and financial questions indicates that he was probably a state employee of the imperial civil administration, in close contact with the environment and culture of apparitores, a class of state employees in the service of Roman magistrates which also included Vitruvius. As a result he is reliable and his proposals are probably real innovations. The machines he describes are not only intended to save manpower which was becoming scarce. What he suggests is an increase in the power of the army thanks to new machines. His treatise, in a way, is not a technical treatise: no one, either today or in antiquity, would be able to build the machines proposed by the anonymous author of De Rebus Bellicis with only the instructions given in the text. It is a theoretical book. Its dating has been much debated but today it is generally agreed that it was written between the reigns of Constance II (337-361 AD) and Theodosius (379-395 AD). In a recent edition, R.I. Ireland suggests spccifically that the book would have been dedicated to Valens at the end of 368 or at the beginning of $369 \mathrm{AD}$ (Ireland 1984).

The text was transmitted via four main manuscripts of the $15^{\text {th }}$ and $16^{\text {th }}$ centuries. Three passages concern the self-propelled liburnian.

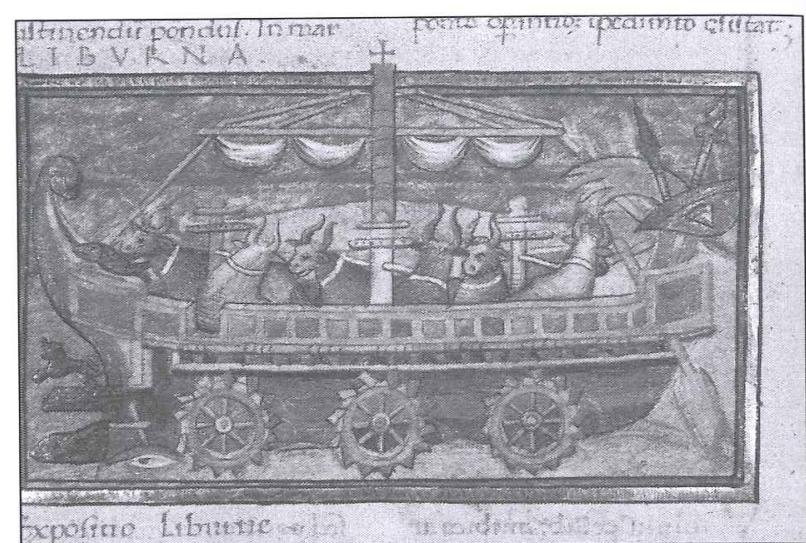

Figure 1. Illustration of the liburnian in De Rebus Bellicis (4 ${ }^{\text {th }}$ century AD) (Manuscript C: Oxon. Canonicianus 378 XV century, Oxford).

It is important to note that the facts are identical in the four main manuscripts.

I shall, in fact, demonstrate how a particularly fast type of warship is able through a brilliant invention to outmatch ten other ships, sending them to the bottom without the aid of a large crew ${ }^{1}$.

A Liburnian ship suitable for naval warfare, so large that human weakness more or less precluded its being operated by men's hands, is propelled in any required direction by animal power harnessed by the aid of human ingenuity to provide easy locomotion. Inside its hull or hold pairs of oxen are yoked to the machines and turn wheels attached to the ship's sides; the spokes project beyond the circumference or rim of the wheels, and, striking the water forcibly like oars as the wheels rotate, work with a wondrous and ingenious effect, their impetus producing locomotion. Moreover this warship, thanks to its massiveness and the machines working inside it, joins battle with such furious strength that it easily crushes and destroys all opposing warships that come to close quarters with it ${ }^{2}$.

But if the enemy flees the land and besets the seas with naval warfare, victory will be restored to you without delay by a warship swiftly traversing the

1 Anon., De rebus bell., Praef. 12.

2 Anon., De rebus bell. 17. 


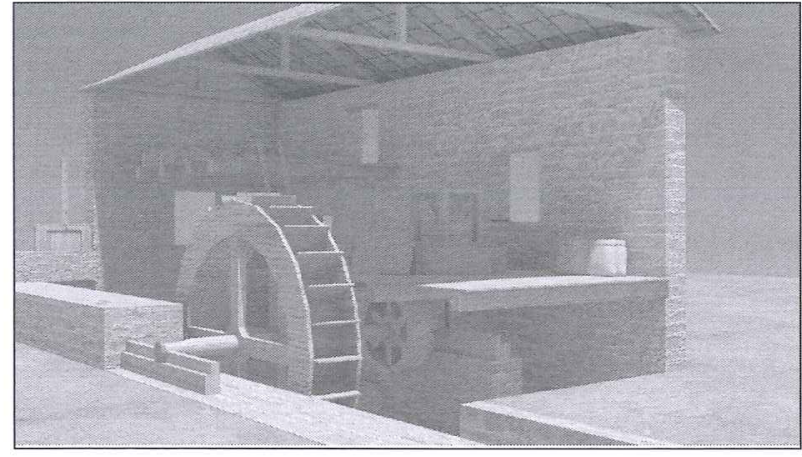

Figure 2. Vitruvius's water mill (1 ${ }^{\text {st }}$ century BC).

waves by means of a new speed device, for it is propelled by wheels and oxen as though it were on land. For who will resist its strength when it has the firmness of a land vehicle and has the advantage of a ship's easy movement? ${ }^{3}$

De Rebus Bellicis was accompanied by illustrations, announced by the author himself and preserved in three of the four manuscripts 4 . These illustrations were probably produced by the author himself or at least checked by him. They thus provide an essential basis for the reconstruction. Concerning the liburnian, variants between the three versions are of little significance.

\section{Indications Confirming Ancient Source Materials}

Therefore, we have a reliable text and an illustration which has accompanied the text from the time of its original writing in the late $4^{\text {th }}$ century $\mathrm{AD}$, but there is no reliable evidence which would allow us to prove that the system was built and used by the Romans. However, a series of indications show that this Roman paddlewheel boat powered by oxen could have been used before the invention of the steam engine and even before the $4^{\text {th }}$ century: on the one hand paddlewheels, gear transmissions and animal mills are widely known in antiquity; on the other hand, while the use of animal mills

3 Anon., De rebus bell. 18, 9-10.

4 Anon., De rebus bell. 6, 5 .

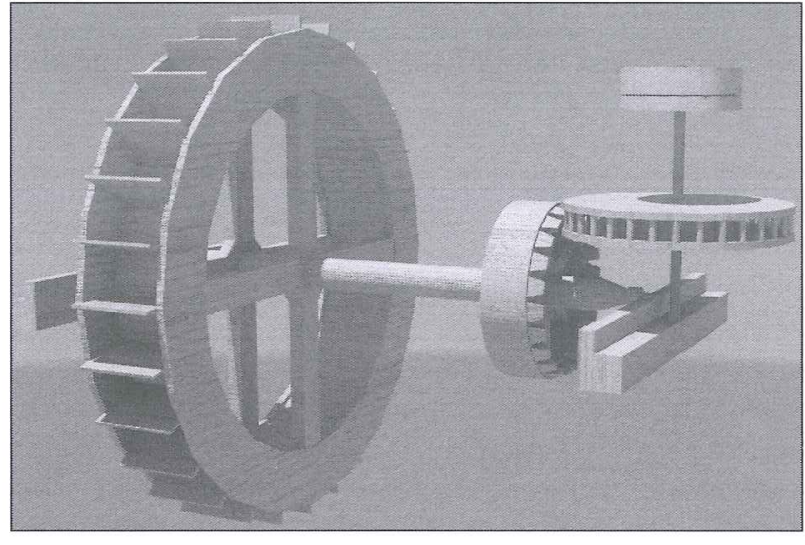

on water seems to have been a rare practice, it is attested to, for certain, in the $19^{\text {th }}$ century.

The paddlewheel has been known since at least the $3^{\text {rd }}$ century BC: Philo of Byzantium describes in his Pneumatics a small paddlewheel which turns using the force of water. In the $1^{\text {st }}$ century $\mathrm{BC}$, Lucretius refers to it and Vitruvius describes water-driven wheels for raising water ${ }^{5}$ (Fleury 1993; Lewis 1997; Wikander 1981).

Following this text, Vitruvius describes a water mill which is based, he says, on the same principle (Fig. 2): its mechanical elements are exactly the same as the ones of the liburnian except that water imparts motion to the paddles instead of vice versa. During the siege of Rome

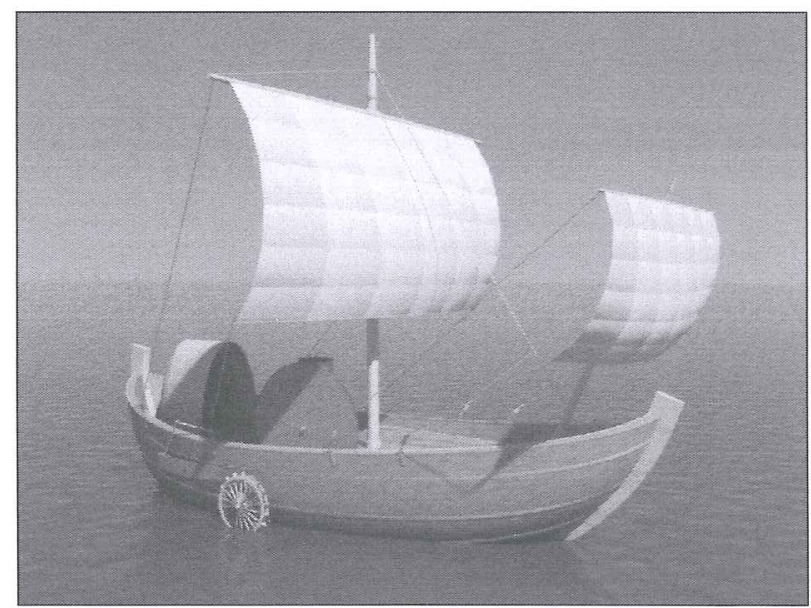

Figure 3. Vitruvius's maritime odometer ( $1^{\text {st }}$ century BC).

5 Vitr. 10, 5, 1. 

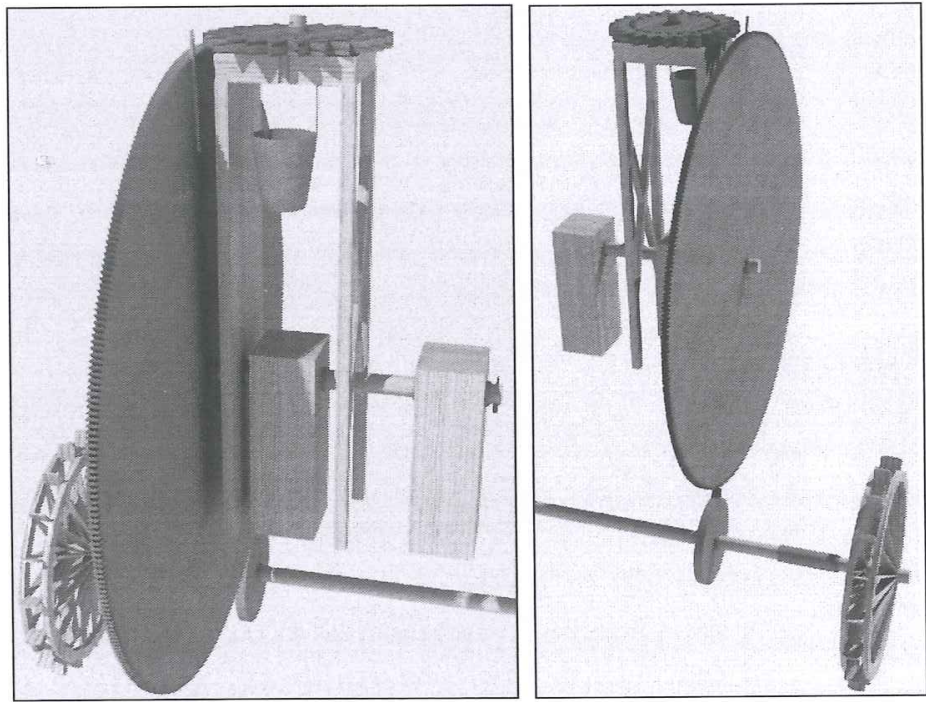

Figure 4. Vitruvius's maritime odometer ( $1^{\text {st }}$ century BC), details.

hoisting machines. Besides textual sources we have for gears, archaeological and iconographic documentation which is certainly not very plentiful but which is sufficient to give evidence of their use in antiquity. These systems were still used in wind mills and water mills in the $20^{\text {th }}$ century (Fig. 5).

The paddlewheels mentioned above drive wheels which activate a system. Except in De Rebus Bellicis, we have no examples of paddlewheels activated by a motive force and used for propulsion. However the type of engine considered here, animal mills, was also well known in antiquity, in particular for the mills of the Pompeian model (Fig. 6) and in systems for raising

in 537-538 AD, Belisarius installed water mills on boats anchored in the Tiber, but this is not the only evidence of paddlewheels on ships: Vitruvius and Heron of Alexandria ( $1^{\text {st }}$ century AD) had already described an instrument that indicates the distance travelled by a ship with paddlewheels (Figs 3 and 4) ${ }^{6}$.

Water mill and odometer imply a gear transmission. These transmission systems were also used in engines for raising water, in machines for sawing, and maybe also in

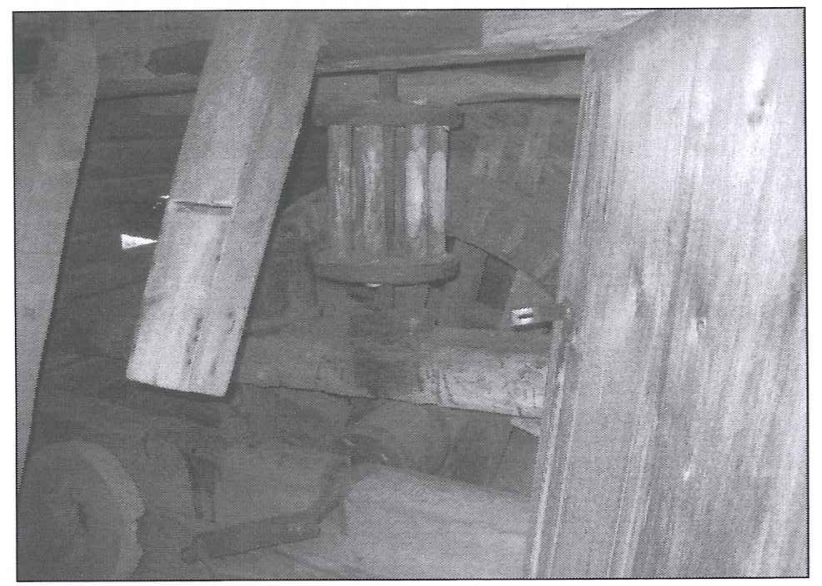

Figure 5. Water mill, Finland, 20 $0^{\text {th }}$ century (Pielisen Museo-Lieksa).

6 Vitr. 10, 9, 5-7. water. It is the principle of the "Persian wheel" or saqiya, a system used in Egypt from the $2^{\text {nd }}$ century BC Is it possible to transpose the principle of the animal mill to a ship? We do not have any serious evidence either from Antiquity or from the Renaissance but, in the $19^{\text {th }}$ century the system is attested in England and described by an engineer who saw it working:

"At Yarmouth the Horse Packet is about 60 feet in length and 18 feet abeam. It is worked by four horses in a file which walk in a circle 18 feet in diameter in which they are much too confined and so do only half the work. The drive-shaft has two bevelled wheels, one at each end, by which the motion is communicated from the horses to the axle of the paddle-wheels 7 feet in diameter. The boat goes at the rate of about six miles an hour" (Stevenson 1946, 59).

On the other hand the usage of animal mills with horses on rafts is attested in Finland in the $20^{\text {th }}$ century for floating wood (Figs 7 and 8).

\section{The Reconstruction of the Liburnian}

From all these elements, we have reconstructed the self-propelled liburnian described in De Rebus Bellicis (www.unicaen.fr/ersam). 
An Ox-powered Paddlewheel Boat. Virtual Reconstruction of a 4th Century Roman Machine Philippe Fleury and Sophie Madeleine

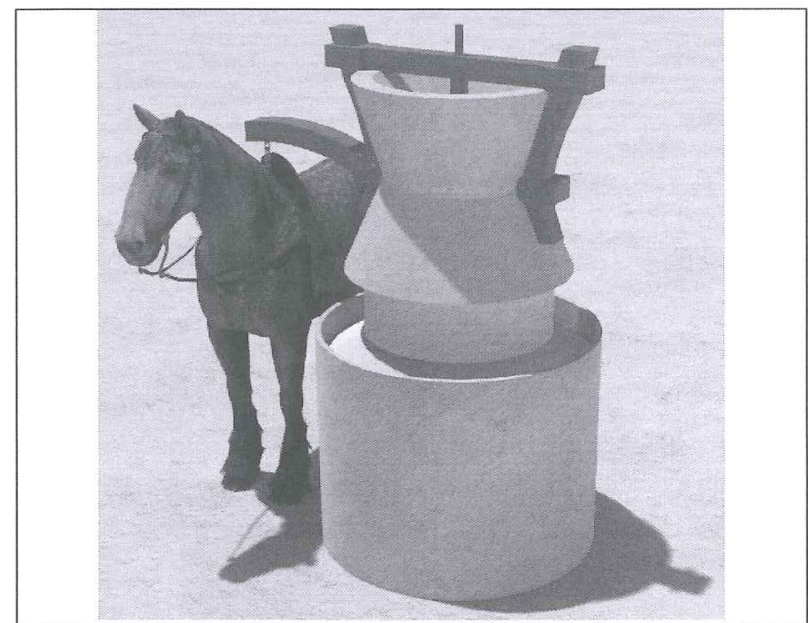

Figure 6. Pompeian mill (1 $1^{\text {st }}$ century AD).

The ship, the system's support, is not part of the project of research presented here in the first version; thus its reconstruction is of a summary and little detailed nature. Vegetius, a contemporary of the anonymous source, uses the word liburna in the sense of "warship". He considers it is the type of ship adopted by the Roman navy since the battle of Actium in $31 \mathrm{BC}$ For him, liburnians can be of several sizes:

With respect to size: the smallest ships of war have a single tier of oars; those a little larger, two; those of good size allot three, four or sometimes five positions for the rowers?

Thus, we shall distrust some modern definitions determining the liburnian as a "low and fast" ship or some definitions of authors further from the anonymous source than Vegetius, such as Lucan or Appian who assimilate the liburnian to a ship with two rows of oars on each side ${ }^{8}$. In reality the word "liburnian" used by the anonymous source does not inform us about the size of the ship: it can be a light or heavy unit. Prudentius, another contemporary, speaks of a liburnian equipped with a tower ${ }^{9}$, thus of

7 Veg., Mil. 4, 37: Quod ad magnitudinem pertinet, minimae liburnae remorum habent singulos ordines, paulo maiores binos, idoneae mensurae ternos uel quaternos interdum quinos sortiuntur remigio gradus.

8 Lucan. 3, 533-534; Appianus, Ill. 3. 9 Prud. C. Symm. 2, 530-531.

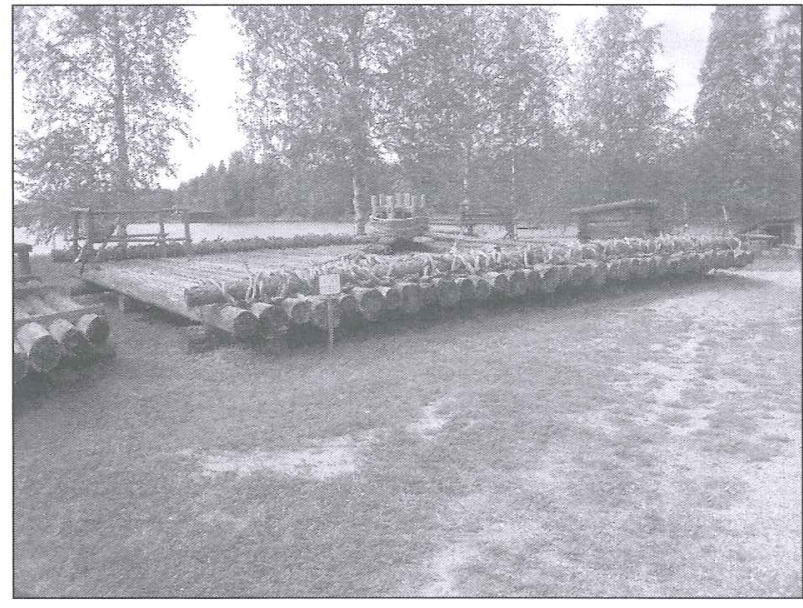

Figure 7. Horse-powered raft for floating wood in Finland, 20 century.
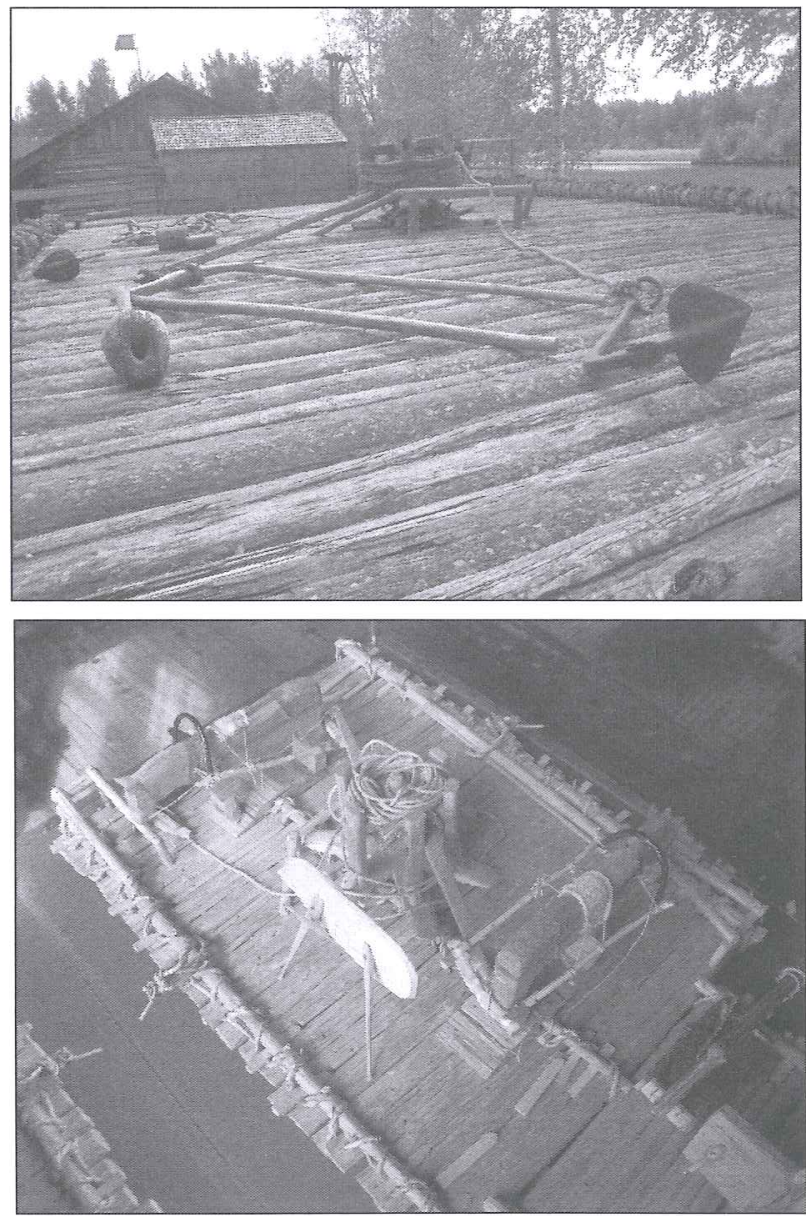

Figure 8. Horse-powered raft for floating wood in Finland (detail and model), 20th century (Finland, XXe Century, Pielisen Museo - Lieksa.) 
CAA2011 - Revive the Past: Proceedings of the 39th Conference in Computer Applications and Quantitative Methods in Archaeology, Beijing, China, 12-16 April 2011
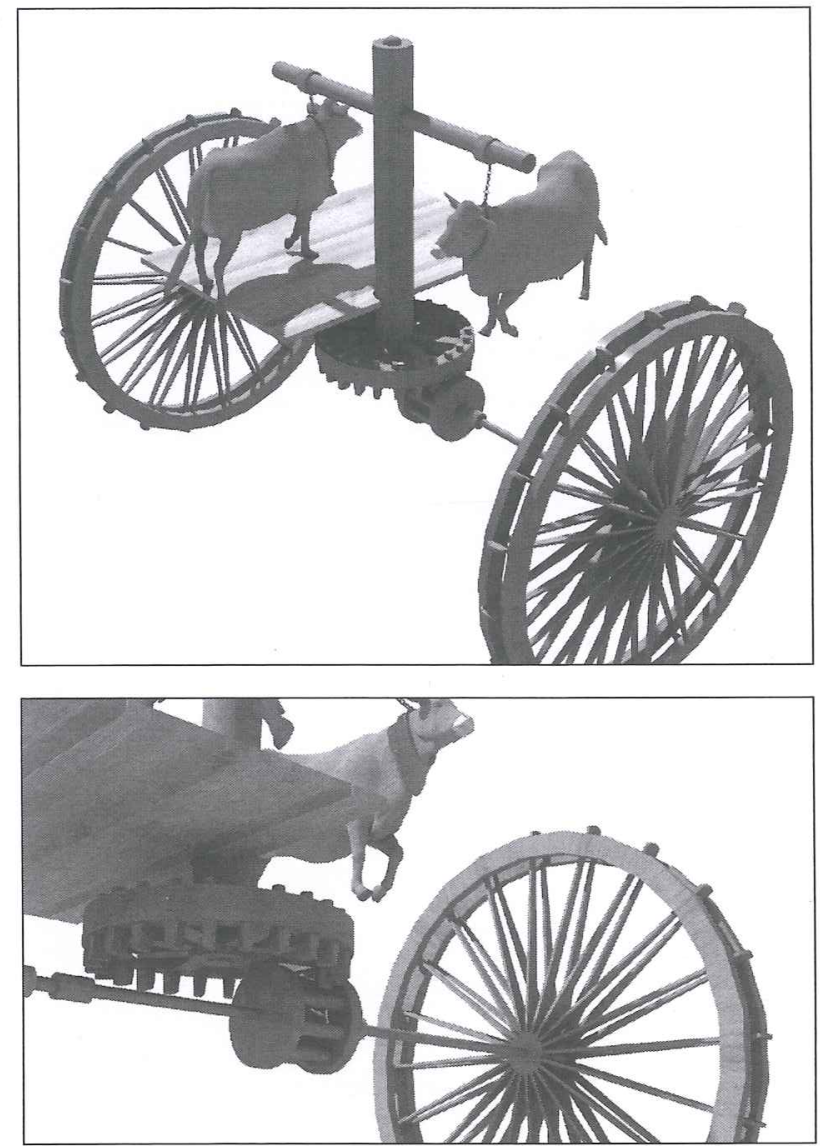

Figure 9: Reconstructed liburnian (4th century AD).

a ship of respectable size (Casson 1971; Starr 1960). For the virtual experiment, we modelled a ship with a length of $35.75 \mathrm{~m}$ and a beam of $5 \mathrm{~m}$. We kept on each side the outrigger for the oars: this is the structure for the paddlewheel axes. The breadth, including outriggers and paddlewheels, is $7.5 \mathrm{~m}$. These dimensions allow the placing of three animal mills with two oxen (Fig. 9), as in the manuscripts' illustrations. The anonymous source does not specify the number of animal mills; he speaks simply of "pairs of oxen yoked to the machines"10. In this first version of the virtual model, as in the manuscripts' illustrations, we placed oxen on the deck of the ship to allow a better visualization of the system, but it is more likely they were placed below. Placing animal mills inside the hull offers a triple advantage: 1) animals are protected from missiles thrown by

10 Anon., De rebus bell. 17,1: bini boues machinis adiuncti. the enemy, 2) the centre of gravity of the ship is lowered, and 3) the deck is clear for soldiers. It is also what the anonymous source means by the expression In cuius alueo uel capacitate, "In its hull or hold". But whatever the position of the animal mills, above or below the deck, the principle of mechanical transmission does not change: it is a question of transforming rotation on a horizontal plane into rotation on a vertical plane.

The virtual reconstruction allows carrying out different experiments. Thus, we suggest fixing to the animal mill's axis of rotation a wooden cogwheel which pulls a lantern, united itself to paddlewheels which are fixed on each side of the ship (Fig. 10). In our reconstruction, the paddlewheels have a $3.5 \mathrm{~m}$ diameter, and thus a circumference of $11 \mathrm{~m}$. An ox, depending on its race and weight, can walk at an average speed of between 2 and $3 \mathrm{~km} / \mathrm{h}$ and supply a onetime effort of up to $4.5 \mathrm{~km} / \mathrm{h}$. We multiplied the speed of the oxen by three with the system of gears. In order for the liburnian to advance at $5 \mathrm{knots}$, the oxen have to walk at $2.6 \mathrm{~km} / \mathrm{h}$; in order for it to advance at $8 \mathrm{knots}$, they have to walk at $4.2 \mathrm{~km} / \mathrm{h}$. Other calculations were made concerning the power developed by the oxen. They show that the total power is relatively low (3hp or $2.1 \mathrm{~kW}$ ) but that it allows the liburnian to advance.

\section{Conclusions}

The virtual reconstruction is a way to show that the liburnian can work (however maybe not as fast and with as much power as the anonymous source claims) and that the system is not "crazy" or "purely imaginary". Therefore it is possible that this boat could have really been built. Why did not the system become more widespread? Why was it necessary to wait for the steam engine to see the development of ships with paddlewheels? At first, the invention of the anonymous source would have a limited use in the navy since the paddlewheel system is cumbersome and vulnerable during a fight. 

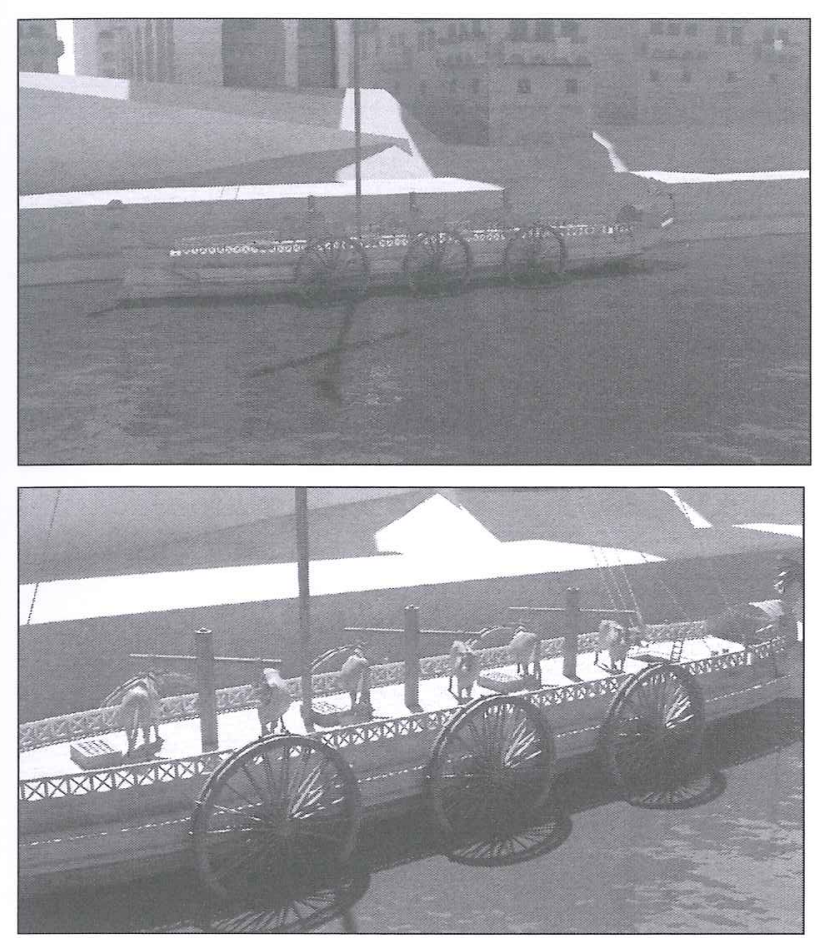

Figure 10. Mechanism of the liburnian ( $4^{\text {th }}$ century $\left.A D\right)$.

Even at the time of the introduction of steam propulsion in the navy in the $19^{\text {th }}$ century, ships with paddlewheels made only a brief appearance and they were very quickly replaced by ships with propellers (Mollat 1970, 9). Secondly this ship is not intended for the open sea: oxen (and other animals) can only work on a calm sea while rowers can contend with pitching and rolling even if the naval actions of antiquity took place only in relatively calm weather. This limits the practical use of this liburnian to rivers, to their mouths and to sheltered bays. But, after all, at this time this was the Roman navy's main field of intervention.

\section{Acknowledgements}

The English text has been proofread and edited by Alice and Edward Mills. We address them all our gratitude.

\section{Bibliography}

Casson, L. 1971. Ships and Seamanship in the Ancient World. Princeton: Princeton University Press.

Condorelli, S. 1971. Riforme e tecnica nel de rebus bellicis. Messina: Sortino.

Fleury, P. 1993. La mécanique de Vitruve. Caen: Presses Universitaires de Caen.

Giardina, A. 1989. Le cose della guerra. Milan: Mondadori.

Ireland, R. I. (ed.) 1984. Anonymous De rebus bellicis. Leipzig: Teubner.

Jouffroy, H. 2004. "Le De rebus bellicis, source d'histoire militaire?" In L'armée romaine de Dioclétien à Valentinien I ${ }^{e r}$, edited by Y. Le Bohec and C. Wolff, 55-67. Lyon: De Boccard.

Lewis, M. J. T. 1997. Millstone and Hammer. The Origins of Water Power. Hull: The University of Hull Press.

Mollat, M. 1970. Les origines de la navigation à vapeur. Paris: PUF.

Reinach, S. 1922. "Un homme à projets du BasEmpire." Revue Archéologique 16:205-65.

Schneider, R. (ed.) 1908. Anonymous De rebus bellicis. Berlin: Weidmann.

Starr, C. G. 1960. The Roman imperial Navy. 31 B.C. - 324 A.D. Cambridge: Cambridge University Press.

Stevenson, A. 1946. English Lighthouse Tours. London: Nelson.

Thompson, E. A. 1952. A Roman Reformer and Inventor. Oxford: Clarendon Press.

Wikander, Ö. 1981. "The Use of Water-power in classical antiquity." Opuscula Romana 13:91-104. 